and "Newton" are generally considered to yield a more valuable mental training than such subjects as analytical geometry is that the older authors, perhaps because they were a bit afraid of purely symbolic argument, tried constantly to keep real pictures and ideas before the minds of their readers. But even so our conviction of the truth of any but the simplest theorems of geometry depends chiefly on the symbolic argument, not on the realization in succession of the actuality of the relations and operations discussed in the course of the proof. This is perhaps sufficiently obvious in the higher branches of even Euclidian geometry, but it becomes absolutely indisputable when we reach such theorems as "Any two conics in one plane intersect in four points." Not only may some of the e points be at an infinite distance, but some, or all, may be what is called, on the lusus a non lucendo principle, "imaginary"; that is, they may be such that they cannot be imagined by anybody, much less actually drawn.

Accordingly I cannot admit that the theorems of geometry are established by induction at all. If they are interpreted in either of the first two ways I have described, they are only particular propositions, and the inference from them to a general proposition would no more yield a "mathematical certainty" in this case than in any other. And though the third way of looking at the proposition may be paraphrased into a form which appears general (e.g., anything which may fairly be called "an isosceles triangle" may also be said "to have two equal angles"), it is really only a particular proposition about the words "isosceles triangle," and so on. Its wide applicability and usefulness depends on the fact that we can, and do, often find things which can fairly be called isosceles triangles; but it must be admitted that the assertion that, on any given occasion, we have found such a thing, -is not a mathematical certainty. If the triangle in question is an objective one, we can only say that it is probably, or approximately, isosceles ; and though perhaps we may subjectively conceive ; erfectly isosceles triangles, and so regard the pons asinorum as a subjective necessary truth, it must be doubtful whether we could do so in the case of a more complex proposition such as Pascal's Theorem, and it is quite certain that we could not d, so in the case of such theorems as that about the intersections of two conics.

It is to be hoped, therefore, that lugicians will come to recognize the importance of symbolic reasoning, as mathematicians have already done. And when they do so we may hope for this further advantage, that they in turn will teach mathematicians and others not to confuse a purely symbolic with a real conclusion-not to assume that, because they have correctly proved a conciusion symbolically, that it therefore necessarily gives any information about real thing;, or even real concepts.

Trin. Coll, Cambs., October 22.

\section{Bell's Idea of a new Anatomy of the Brain.}

IN NATURE of Ostober 27 the writer of the review of $\mathrm{Mr}$. Horsley's "Structure and Functions of the Brain," speaking of the rarity of the above book, states that he only knows of one copy in London, viz., that in the British Museum. It may be useful to some of your readers to know that there is a very interesting copy in the library of the Royal College of Surgeons. It is the presentation copy to Dr. Roget " from Mr. C. Bell, 34, Soho Square" : by Dr. Roget it was given to Lady Bell, who pre sented it to the Royal College of Surgeons through Mr. Alexander Shaw.

Mr. Shaw has added in MS. a copy of the letter received from the printers fixing the original date of publication, and also the list of persons to whom presentation copies were sent. The letter and the list are both published in Mr. Shaw's reprint of the Tract in the Fournal of Anatomy, ol. iii., 1869.

October 27 . Jas. B. BaILey,

\section{Photographic Dry Plates.}

IN reference to "Prevention's" note on Photographic Dry Plates, one cannot but agree with him that packets should be dated when issued from the factory.

I would venture, however, to suggest that good makers' plates do not deteriorate within a reasonable length of time.

As an illustration of my experience I may mention that in April this year I opened a box of plates ( $\frac{1}{2}$ plate Extra Rapid) which I bought in July 1886 .
I had carried them on a three months' tour in the Mediterranean in 1888 and had taken no special care of them since.

They proved in every way as good as new, both in sensitiveness, and perfection and evenness of film.

Arthur E. Brown.

\section{THE GENUS SPHENOPHYLLUM.}

NOTWITHSTANDING the small size and comparative scarcity of the plants belonging to this Palæozoic genus, they have long attracted a rather unusual amount of attention. This has been partly due to their peculiar external forms, which suggested even to the earliest observers the idea of resemblances to the Marsiliæ; but the interest they have excited has been further increased of late years by discoveries respecting the peculiar organizations of their stems. In $1822 \mathrm{Adolph}$ Brongniart assigned to them the name of "Spenophyllites," and in 1823 Sternberg figured some of them under the generic title of "Rotularia." Sternberg's figures appeaied in his "Versuch einer GeognostischBotanischen Darstellung der Flora der Vorwelt," which work is now best known through the French translation of it by Comte de Bray. To the first of his specimens figured (loc. cit., tab. xxvi., figs. $4 a$ and $b$ ), Sternberg gave the name of Rotularia pusilla, and the example so designated is very characteristic of the simpler type of the group, in which we have a somewhat branched stem, with verticils of wedge-shaped leaves at each node. A second form was figured on a later plate of the same work. It is interesting to note that Sternberg associated with these figures the observation, "Plantæo organisatione foliorum Marsileis, forma caulis Hippuri Maritimæ." The generic name thus given by this author represents the rotate arrangements of the leaves in each verticil, as the wedge-shaped contour of each separate leaf is further indicated by Brongniart's generic term, "Sphenophyllites." In I 820 Von Schlotheim had also included similar examples in his too comprehensive genus, "Palmacites."

In 1828 Brongniart published his classic "Prodrome d'une Histoire des Végétaux Fossiles," in which work we find the generic name of these plants changed to Sphenophyllum, which name they have retained to the present time. In this work Brongniart examines in some detail the probable affinities of these plants, which even in 1822 he inclined to regard as having some affinities with the Marsileæ. He defines them as having six, eight, ten, or twelve leaves in each nodal verticil, each leaf being wedge-shaped ; sometimes entire, truncated at its apex, which is denticulate. In some others these leaves are bilobed, and in other species they are not only profoundly bifid, but each of these lobes is either divided into two, or their ends are laciniated. Lastly, in some cases the lobes become narrow and linear. Brongniart here compares these leaves with those of Ceratophyllum and Marsilea, concluding with the statement, "We cannot for the moment decide between these two relationships." At this date the fructification was wholly unknown.

In his introduction to the "Natural System of Botany," p. 37 , Brongniart again reverts to the idea that Sphenophyllum had Marsileaceous affinities.

In I83I the authors of the "Fossil Flora of Great Britain" commenced their publication of that work, and in one of its early numbers they figured and described under the name of Spenophyllum erosum what appears to be identical with the first figure published by Sternberg. When discussing the relationships of this plant, Lindley and Hutton

$x$ These figures were preceded in 1709 by a still earlier one by Scheuchzer in his "Herbarum Diluvianum." (Coemans and Kickz, "Moaographie des Sphenophyllum d'Europe").

2 "Die Petrefactenkunde auf ihrem je:zigen Standpuncte," 
reject Brongniart's idea of its possible affinity to the Marsilew, inclining to the belief that it approached nearer io the Coniferx, and espccially to Salisburia. This impression they retained when, at a later date, they described a second species of the same grenus.

In his "Tableau des Genres de Végćtaux Fossiles," published in 1849 , Brongniart returns to the subject. He here calls attention to the readiness with which Sphenophyllum may be confounded with the genus Asterophyllites, which some forms of the former genus closely resemble; but he again repeats that the two can be distinguished by the fact that in the former genus the leaves never exceed ten in number, whilst their form is triangular with a truncated summit. He again divells upon the fact that in some Sphenophylla the leaves become so deeply lobed, narrow, and linear, as to be easily mistaken for those of Asterophyllites. He now affirms that the fructification is closely related to that of Asterophyllites.

As to the affinities of Sphenophyllum, Brongniart now asks, "Does the plant combine the leaves of a Marsilea with the verticillate of an Fquisctum, or is it a Grmnospermous Phanerogam, the leaves of which approach those of the Gingko?" He does not answer the question, but concludes that this cannot be done until the fructification of the plant is better understood.

In ISG+ a monograph on the species of the genus was published by .I. Fugene Cuemans and M. J. Kickz; but the authors make no serious effort to solve the vexed question of the affinities of the genus.

We now enter upon a new stage in the history of the senus. In 1870, M. Renault presented an important memoir to the French Academy of Science, which, for the first time, threw light upon the internal organization, especially of the stems, of Sphenophyllum. He described two examples, one from Autun and the other from St. Etienne, both of which exhibited a structure wholly diflerent from that of any p!ant previously known, recent or fossil. In the centre of each stem was a primary vascular bundle, the transverse section of which was a triangle with three concave sides and three prolonged, narrow, intermediate arms. This axial organ underwent no subsequent growth after its first formation. But it was invested by a secondary zone, which was deposited upon the primary triangle lityer after layer like a secondary xylem, producing a circular axis, which enlarged as the plant advanced in age. But this secondary growth did not consist of layers of vessels, but of vertical columns of thick-walled cubical cells. The cortex also exhibited specially distinctive features. These discoveries made it clear that Sphenophyllum constituted, not only a very distinct genus, but a type of plant far removed from everything previously described.

It fell to my lot to make the next advances in our knowledgre of this genus. In 1871 I described in the memoirs of the I.iterary and Philosophical Society of Manchester a new fructification, to which further reference will be made later on. In 1872 I obtained from the Oldham deposits some new stems which obviously belonged to the same type as thuse discovered by M. Renault, but from which they differed in important points of detail. 'These were described in my Memoir, Part $V$. published in the Philosophicial Transactions for 1874 . Transverse section; of these closely resembled in their dominant features .M. Renault's corresponding ones, but with two differences. When my plants attained to a certain stage of their exogrenous growth, a well-defined circular boundary marked a temporary arrest of that yrowth, but which started afresh from a zone of much smaller vessel; (loc. cit. Pl. 11., Figs. I I and I2), that increased in size as the diameter of the axis increased, as they had previously done in the more internal series. Sitill greater and more important differences presented themselves in the longitudinal sections.
The zones of secondary or exogenously developed xylem, which in M. Renault's examples consisted solely of verticolumns of thick-walled, cubical cells, were composed, in mine, of true tracheidal vessels with reticulated (not with bordered pits) walls; presumably a higher stage of devclopment. Another new and more advanced feature than characterise Renault's cells, seen best in tangential sections of this zone (loc. cit. Fig. I3), was the existence, between contiguous tracheids, of vertical, but interrupted, series of small cells, which I can only regard as rudimentary medullary rays. In the same memoir (loci. cit. Pl. IV.) a still more distinct form from the Burntisland deposits in Fifeshire was figured and described. M. Renault and Count Solms Laubach refuse to recognize a Sphenophyllum in this type, but they have not yet convinced me that 1 am in error on the point. The fact is that, though widely aberrant from the form described above, it scarcely differs more from that form than the latter does from M. Renault's examples.

But my Oldham specimens raised another debated question. When the Memoir $V$. was published, all authorities agreed that the maximum number of true leaves in each verticil was ten or twelve; that, however deeply subdivided, their outline was a sphenoid one, and not linear, and that they were multinerved. But I am still convinced that in my specimens there were more than twenty such leaves; that they were linear in outline, and had a single median nerve. It followed that, continuing to accept the existing definitions of the genus Sphenophyllum, my plant was Asterophylloid rather than Sphenophylloid. I am now prepared to admit that it is a Sphenophyllum; but only on the condition that we alter our definitions of the latter genus, and admit the possibility that some of the forms may possess twenty or more undivided and linear leaves. The accumulating evidence that the foliage of at least some of the Sphenophylla was dimorphic makes the acceptance of my proposition a matter of necessity.

Yet more recent researches have revealed new and important facts connected with the history of these plants. I have already alluded to the new fructification which I described in I87I, and to which I gave the name of Volkmannia Iuzisoni. M. Renault's memoir already noticed was laid before the French Academy in May IS70, and noticed in the Comptes Rendus of that date; but owing to accidents growing out of the Siege of P'aris, it was not published until three years later. Meanwhile my memoir on Volkmannia Dawsoni was published, and a copy of it forwarded to M. Brongniart. After giving details of the structure of the strobilus I arrived at the conclusion that " it is the fruit either of Asterophyllites or of Sphenophyllum."

'Two years later M. Renault's memoir of 1870 was combined with a second one on the same subject, and published. It contained a note by M. Brongniart, referring to my memoir of 187 I, in which note he says, "This work agrees in many important points with the results obtained a year previously by .M. Renault, though Mr. IVilliamson was unacquainted with the article in the Comptes Rendus of May 30, 1870. The fossil plant studied by Mr. Williamson, and named by him Volkmannia llawsoni, doubtless differs, at least specifically, from that described by M. Renault, by the form of the central vascular bundle, and by the absence of the zones of quadrangular cells which surround it in the French specimens; cells which in consequence of the thickness of their walls would not be readily destroyed." 1

II. Lrongniart has here failed to comprehend an important point. The cells, the absence of which he notices, really belunged to the secondary xylem of the older stem, which did nut become developed in the younges twigs. But it was only upon these twigs that the fructifications were formed, and of which they were but extensions. Hence their absence wa merely a consequence of difference of age, and not a feature of specific value. 
In 1890 I figured in my Memoir XVIII. (Phil. Trans. 1890) a transverse section of what was obviously a stem of Bowmanites Dawsoni, in which the primary triangular axis of the strobilus was invested by a thick zone of the secondary xylem. So far as the arrangement of its tissues is concerned this stem is constructed on exactly the same plan as appears in M. Renault's and my own Sphenophylla. In describing it I further said, "We must unite Sphenophyllum with some forms of Asterophyllites in the same genus. It is equally clear that Bowmanites, though its peculiar fructification demonstrates that it constitutes a perfectly distinct genus, has strongly marked features of affinity in the structure of its stem to the Sphenophylloid type."

The above reference to differences between the fructification of Bowmanites and of Sphenophyllum were based upon the minute description of the fruits of the latter plant, published by M. Renault ("Etudes sur le Terrain Houiller de Commentry," pp. 48I-2). Those descriptions differ widely from what exists in my Bowmanites, but $M$. Renauit distinctly identifies them with the fructification of Sphenophyllum. I obtained additional and important specimens of Bowmanites in 1890 , which threw much new light upon its organization, and which were recorded in my Memoir XVIII. (Phil. Trans. I891).

In July last an important communication was laid before the Academy of Sciences by my friend M. Zeiller the distinguished director of the Superior National School of Mines at Paris. In it he records his identification of a fructification of a Sphenophyllum of the type of $S$. pusillum of Sternberg and S. erosum of Lindley and Hutton, with my Bowmanites Daresoni. If this determination is correct, and I see no reason for doubting that it is so, we now have some more definite facts than we have hitherto possessed, guiding us alike in identifying the true fructification of Sphenophyllum and in determining its position in the vegetable kingdom.

Before explaining M. Zeiller's observations more in detail, a few words explanatory of the structure of Bowmanites will make M. Zeiller's views more intelligible to the reader.

The accompanying diagram represents two nodes and

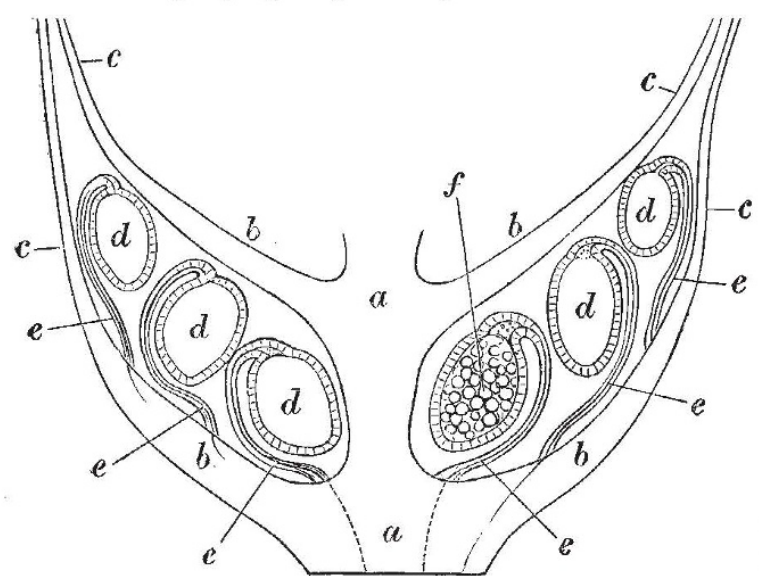

one internode from a vertical section of this fruit, with the sporangia and three sporangiophores in situ.

So far as external contours are concerned, it is undistinguishable from many of the true Calamarian forms of fructification. It is only when cut into sections that its characteristics can be discovered. Its central axis $(a)$ has nodes $(b)$ at short and regular intervals, and at each node is a verticil of from 16 to 20 sporophylles or fertile bracts $(c)$. At their basal portions these bracts are coalesced into a lenticular disk $(d)$, from the margin of which the thinner and narrowing bracts extend upwards, overlapping from two to three internodes. From the upper surface of the disk numerous slender sporangiophores (e) spring, each one proceeding upwards and outwards, to become attached to the upper or distal extremity of a large oval sporangium $(f)$. Each of these sporangiophores has running through it a small bundle of barred tracheids, which terminate at the point of attachment to the sporangium. Each tracheal bundle is a prolongation of one of a circle of similar ones that ascend from the central axis into the disks. These fructifications, besides being manifestly eusporangiate, are extremely characteristic of the plant, nothing identical with them having been observed by any of the authors who have investigated the Carboniferous strobili. After these illustrations I will allow M. Zeiller to explain his views in his own words. After referring to the details given in my Memoir XVIII., M. Zeiller says :-

"L'aspect de ces sporanges, ainsi attachés au bout de ces pédicelles recourbés, est exactement, à part les dimensions moindres, celui de sporocarpes de Marsilea. L'analogie parait du reste n'être pas purement superficielle; M. Williamson a reconnu en effet, dans le pédicelle de chaque sporange, un cordon vasculaire bien caractérisé, qui prouve qu'on n'a pas affaire là à une simple formation épidermique, comme pour les sporanges de Fougères ou de Lycopodinées. Il faut, à ce qu'il semble, regarder ces pédicelles comme représentant des lobes ventraux des bractées, analogues au lobe fertile des frondes d'Ophioglossées, ou à ceux des Marsiliacées ; seulement ils portent à leur extrémité non pas une série de sporanges comme chez les premières, ou plusieurs sores comme chez ces dernières, mais un sporange unique à paroi formée d'une seule assise de cellules."

"De cette constitution des épis du Sphen. cuneifolium" il report que, si les Sphenophyllum rappellent les Lycopodinées par la structure de leur axe, ils s'en éloignent notablement par la disposition toute spéciale de leur appareil fructificateur, qui tend à les rapprocher plutôt des Rhizocarpées, et qu'ils doivent donc bien décidément être considéré comme formant une classe distincte parmi les Cryptogames vasculaires."2 Agreeing thoroughly with these conclusions further comments are needless. WM. CRAWFORD Williamson.

\section{DENDRITIC FORMS.}

THE curious appearances presented by certain native specimens of silica have been observed for so long, that it is somewhat surprising that so little is known about their real constitution and mode of formation.

Rock-crystal is frequently found to contain bubbles of liquid, usually either water, carbon dioxide, or petroleum, or crystals, such as scales of mica, forming aventurine, and fibres, such as asbestos, forming cat's-eye. More rarely, however, forms of apparently vegetable origin are seen ; one of the most remarkable specimens is a prolate spheroid, about five inches long and four inches across, cut from a clear colourless rock-crystal, in which are embedded numerous fragments about the size of a large pea, presenting the exact appearance of club-moss.

Agate is frequently found with distinct coloured layers, either flat or distorted, and usually milk-white, red, brown, or black. It is then known as onyx.

More rarely, agates are found with markings like moss or foliage distributed through them; they are then known as moss-agates, or Mocha stones.

In 18 I 4 , Dr. J. MacCulloch described some cryptogamic forms in the agates of Dunglas (Geological Trans., ii.,

\footnotetext{
$x$ The species of Sphenophyllum to which M. Zeiller's strobili were attached.

${ }^{2}$ Comptes Rendus des Séances de l'Académie des Sciences, Paris, July $x, x^{2} 92$.
}

NO. I 2OI, VOL. 47] 